\title{
Soil enzymes as indicators of long-term sewage sludge compost application
}

\author{
Marianna MAKÁDI - Ibolya DEMETER - Viktória OROSZ - Ferencné KASI - \\ Tibor József ARANYOS \\ University of Debrecen IAREF Research Institute of Nyíregyháza, Westsik Vilmos u. 4-6. Nyíregyháza, \\ Hungary; E-mail: makadim@gmail.com, ibolyad85@gmail.com, oroszviki1000@gmail.com, aranyostibi@ \\ gmail.com,
}

Keywords: invertase, catalase, sewage sludge compost, regular application

\section{Introduction}

Extracellular soil enzymes have important ecological role for microbes and higher organisms. They have dual functions as degradation of complex organic material and resource acquisition for the enzyme producers (Sinsabaugh, 1994). Therefore, the enzyme quantity in soil is determined by the nutrient demand of host organisms and the presence of the target molecules of enzymes in the soil. High quantity of an enzyme can be produced when its target molecule is in the environment. This strategy is very cost-effective for the microbes (Allison et al. 2011). Sewage sludge compost (SSC) is a continuously produced by-product containing organic material. If its organic and inorganic pollutant content is low, it can be utilized as a nutrient source and soil improving material. Our aim was to compare the changes in soil microbiological and chemical properties in the third and fifth application cycle of SSC and to prove the importance of long-term experiments for evaluation of the environmental effects of regular SSC application.

\section{Materials and methods}

The small plot experiment was established on Dystric Lamellic Arenosol (WRB) on the field of Research Institute of Nyíregyháza, IAREF, University of Debrecen in 2003. 0, 9 , 18 and $27 \mathrm{t} \mathrm{ha}^{-1}$ doses of SSC containing $40 \%$ of sewage sludge, $25 \%$ of straw, $30 \%$ of rhyolite and $5 \%$ of bentonite are applied in every third years. Soil is sampled from the 0-30 $\mathrm{cm}$ soil layer in every autumn for chemical and microbiological analysis. Soil chemical analysis (pH, macro-, meso and toxic elements) were done according to the Hungarian standards. Catalase activity was calculated from the released $\mathrm{O}_{2}$ from $\mathrm{H}_{2} \mathrm{O}_{2}$ amended soil samples (Hungarian Standard MSZ-08-1721/4-86). Invertase activity was measured according to Mikanová et al. (2001) on the base of glucose formation. Data obtained were statistically analysed yearly by analysis of variance. For comparison of the means Tukey's test were used after ANOVA. With the whole database (26 soil parameters) of the years 2007 and 2015, Principal Component Analysis (PCA) was done. The significance level was $\mathrm{p}<0.05$.

\section{Results and discussion}

Changes of catalase and invertase activities was found different in the studied periods. Catalase activity refers to the general metabolic activity of aerobic soil microorganisms. Its measured values were similar in the control plots between 2007 and 2015 (1.25-1.49 $\mathrm{mg} \mathrm{O}_{2} \mathrm{~g}^{-1}$ dry soil $\mathrm{h}^{-1}$ ) while a continuous increase of its value was found in the treated plots with increasing SSC doses $\left(9 \mathrm{t} \mathrm{ha}^{-1}: 1.41-1.75 ; 18 \mathrm{t} \mathrm{ha}^{-1}: 1.39-2.06 ; 27 \mathrm{t} \mathrm{ha}^{-1}: 1.48\right.$ - 
$1.97 \mathrm{mg} \mathrm{O}_{2} \mathrm{~g}^{-1}$ dry soil $\left.\mathrm{h}^{-1}\right)$. SSC contains organic and mineral colloids which could adsorb and protect extracellular enzymes. Moreover, montmorillonite could increase the activity of catalase (Stotzky, 1974). Treatments differed significantly from the control in the fifth application period and indicated the increase of general bacterial activity after SSC application. Invertase enzyme are responsible for the destruction of disaccharides to monosaccharides which means that this enzyme is on the end of the destruction of high molecules of organic matter. The activity of invertase was varied year by year both in the control and treated plots. Its values were between 0.296 and $4.451 \mathrm{mg}$ glucose $\mathrm{g}^{-1}$ dry soil $4 \mathrm{~h}^{-1}$ in the control treatment with similar order of magnitude in the treated plots which indicated the strong effect of the environmental factors on the invertase activity. Significant differences among the treatments were not found but the invertase activity was somewhat higher in SSC treated plots. Based on the results of these two enzymes we can state that SSC application can increase the microbial activity of soil. However, enzyme activities generally are effected by soil chemical properties (Gianfreda et al., 2005). Therefore, the complex -chemical and microbiological- analysis of soils could result in more reliable evaluation of changes in soil processes and quality. Analysis of all measured chemical and microbiological data with PCA indicated the continuously increasing difference among the treatments.

\section{Conclusions}

Regular application of sewage sludge compost resulted in continuous changes in soil quality. Soil enzymes refer to special or general processes and can indicate the treatment effects on different level, but more accurate results could be available by complex analysis of chemical and microbiological data. In our long-term experiment both the studied soil enzymes and the complex data analysis revealed the continuous changes of chemical and microbiological properties of SSC treated soils.

\section{Acknowledgement}

The establishment of the long-term experiment is supported by Nyírségvíz Ltd., Nyíregyháza, Hungary.

\section{References}

Allison, S.D., Weintraub, M.N., Gartner, T.B., Waldrop, M.P. (2011): Evolutionary-economic principles as regulators of soil enzym production and ecosystem function. In: Shukla, G., Varma, A. (eds.): Soil Enzymology, Soil Biology 22. Springer-Verlag Berlin Heidelberg. pp. 229-243. DOI: 10.1007/978-3-64214225-3_12

Gianfreda, L., Rao, M.A., Piotrowska, A., Palumbo, G., Colombo, C. (2005): Soil enzyme activities as affected by anthropogenic alterations: intensive agricultural practises and organic pollution. Science of the Total Environment, 341: 265-279.

Mikanová, O., Kubát, J., Mikhailovskaya, N., Vörös, I., Biró, B. (2001): Influence of heavy metal pollution on some soil-biological parameters in the alluvium of the Litavka river. Rostlinna Vyroba, 47: 117-122.

Sinsabaugh, R.L. (1994): Enzymic analysis of microbial pattern and processes. Biology and Fertility of Soils 17: $69-74$.

Stotzky, G. (1974): Activity, ecology and poplation dynamics of microorganisms in soil. In Laskin, A., Lechevalier, H. (eds.): Microbial Ecology, pp. 231-247. CRC Press, Cleveland, OH. 